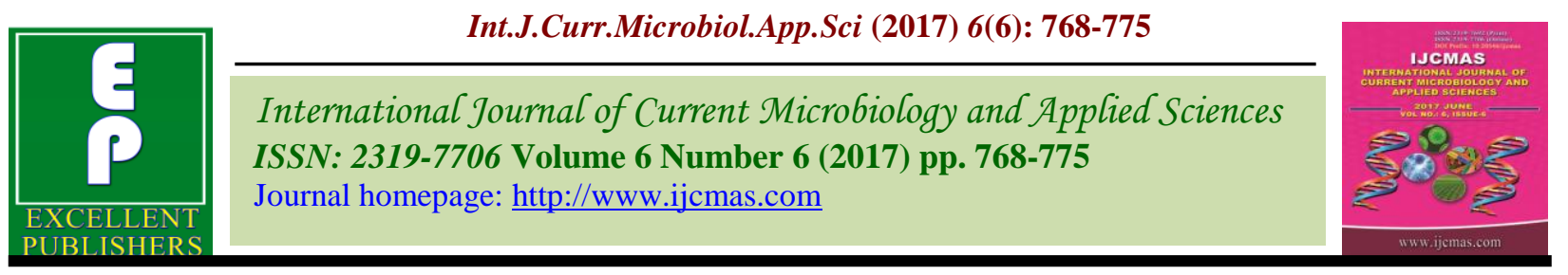

Original Research Article

https://doi.org/10.20546/ijcmas.2017.606.090

\title{
A Study on Foliar Feeding of GA3 and NAA on Vegetative Growth and Yield of Phalsa (Grewia Subinaequalis D.C.)
}

\author{
Bhujbal Singh*, A.L. Yadav and Ashok Kumar Meena \\ Department of Horticulture, College of Horticulture \& Forestry, N.D.U.A \&T, \\ Faizabad-224 229, India \\ *Corresponding author
}

\section{A B S T R A C T}

\begin{tabular}{|l|}
\hline Ke y w o r d s \\
Phalsa, \\
Plant growth \\
regulator, \\
Plant growth, \\
Yield, \\
Foliar spray. \\
\hline Article Info \\
\hline $\begin{array}{l}\text { Accepted: } \\
\text { 14 May 2017 } \\
\text { Available Online: } \\
\text { 10 June 2017 }\end{array}$ \\
\hline
\end{tabular}

The experiment was conducted at Main Experiment Station, Horticulture, Narendra Deva University of Agriculture and Technology, Kumarganj, Faizabad, Uttar Pradesh during 2014-2015 in Randomized Block Design with three replications and seven treatments; T1 - Control (Water spray), T2- NAA 100 ppm, T3- NAA 150 ppm,T4- NAA 200 ppm,T5- GA350 ppm,T6 GA3- 100 ppm,T7 GA3-150 ppm. Growth attributes like shoot length, number of shoots per plant, number of leaves per shoot, inter nodal length, yield attributes like number of fruits per node, number of fruiting nodes per shoot, fruit yield per plant $(\mathrm{kg})$, fruit yield per hectare $(\mathrm{q})$. Foliar application of GA3 @150 ppm is effective to increase vegetative growth, yield in phalsa fruits. Hence GA3 150 ppm can be recommended for phalsa growers for higher yield.

\section{Introduction}

Plant growth regulators are signal molecules produced within the plant, and occur in extremely low concentrations. Hormones regulate cellular processes in targeted cells locally and, when moved to other locations, in other locations of the plant. Hormones also determine the formation of flowers, stems, leaves, the shedding of leaves, and the development and ripening of fruit. Plant hormones shape the plant, affecting seed growth, time of flowering, the sex of flowers, senescence of leaves, and fruits. Plant growth regulators improved yield of fruit plants (Chandra et al., 2015, Chaudhary et al., 2013, Chundawat and Randhawa 1973, Debnath et al., 2011, Sharma and Dhillon 2015, Sharma et al., 2003). They affect which tissues grow upward and which grow downward, leaf formation and stem growth, fruit development and ripening, plant longevity, and even plant death. Hormones are vital to plant growth, and, lacking them, plants would be mostly a mass of undifferentiated cells. So they are also known as growth factors or growth hormones. Phalsa is a hardy fruit plant well suited for cultivation under adverse climatic condition. Although fruits are quite nutritive and have medicinal value, Phalsa bushes are rarely manure in India. Moreover, no schedule based nutritional approaches has yet 
been standardized for phalsa. Hormone is an important and vital aspect of plant life. However, a great deal of variation in various regions of world with respect to its quantity exists. Methods of application and quality of hormones incorporation differ in all the fruit trees. The relevant information's available on plant growth regulators studies in phalsa and other fruit crops used as base for planning and execution of the present study are reviewed in this chapter under following heads. Higher inter-nodal length achieved might be due to cell division, cell elongation and growth enhancing properties of gibberellin reported by Singh et al., (2015) with the spray of 20 ppm GA3 and Kumar e.t al. (2014) in phalsa, GA3 influence vegetative and reproductive growth hence it increases yield of fruit plants (Kachaet al., 2012, 2014, Kumar et al., 2014, Singh et al., 2011, Grewal et al., 2000, Yadav and Pandey 1974). The increase in growth and yield attributes particularly number of shoots per plant, number of fruiting nodes per shoots, number of fruits per node and increased yield per plant which contributed towards such an increase in average yield per hectare.

\section{Growth attributes}

Pandey and Narwadkar (1984) found that spraying of urea and auxin indicated more vegetable growth over control on mango $\mathrm{cv}$. Dasheri.

Moon Young et al., (2003) noted that foliar application of GA3 (at 0, 25, 50 and 100 $\mathrm{mg} / \mathrm{liter}$ ) in Satsuma mandarin, increased the number of vegetative shoots, fruit set and fruit size.

Rajput et al., (2011) founded that spraying 200 ppm NAA increased the leaf index, length of flower panicles, fruit set, reduction of malformation and even the bio-chemical status like carbohydrate, nitrogen and enhanced RNA and DNA level. Whereas length of terminal shoots, percentage of hermaphrodite flower and level of mangiferin was enhanced by $50 \mathrm{ppm}$ GA3 recorded in mango tree.

Singh et al., (2011) reported that foliar application of GA3 at $50 \mathrm{ppm}$ increased number of leaves size of phalsa and fruit set.

Choudhary et al., (2013) revealed that application of GA3@ 100 ppm showed superior results with respect per cent increase in plant spread $(20.59 \%)$ and crown volume $(38.42 \%)$ over control on 150 days after treatment of Nagpur mandarin.

Kumar et al., (2014) reported that the shoot length, number of shoots, leaves, internodal length, number of fruits, fruiting node and yield were recorded maximum significantly with foliar application of GA3 @ 20ppm + NAA @50ppm+ZnSO4@0.4\%+Urea@ 2\% followed by GA3 @20 ppm + Urea @ 2 $\%$ whereas minimum with control in phalsa.

Karole and Tiwari (2016) revealed that Maximum values for leaf length $(1.70 \mathrm{~cm})$, leaf width $(1.49 \mathrm{~cm})$ and leaves/shoot were recorded with foliar application of $60 \mathrm{ppm}$ $\mathrm{NAA}+30$ ppm GA3 $+2.0 \%$ urea followed by 40 ppm NAA +20 ppm GA3 $+1.5 \%$ urea whereas minimum in control of ber.

\section{Yield attributes}

Rema and Sharma (1991) reported significantly maximum fruit weight and volume with the application of $150 \mathrm{ppm}$ NAA or $480 \mathrm{ppm}$ Ethrel [ethephon] + $150 \mathrm{ppm}$ NAA during full bloom, whereas total soluble solids were also recorded with the 480ppm Ethrel during full bloom, as well as after applying 920 ppm Ethrel or 960 ppm Ethrel + 2.5ppm 2,4D one week before harvesting in phalsa fruit. 
Oosthuyse (1993) noted that foliar application of CPPU (10 ppm) + GA3 (40 ppm), NAA $(40 \mathrm{ppm})+\mathrm{GA} 3(40 \mathrm{ppm})$ after flowering increases fruit retention in mango $\mathrm{Cv}$. Tommy Atkin.

Brahmachari and Rubi (2001) stated that spraying of GA3, Kinetin and Melic Hydrazide increase fruit retention and reduced fruit drop in litchi cv. Purbi.

Brahmachari and Rubi (2000) advocated that foliar application of 2, 4, 5-T (50-100 ppm), GA3 (100-200 ppm), CCC (500-1000) Cu (NO3)2 and $\mathrm{CuCl} 2$ (82\%) increased fruit retention.

Ingle et al., (2001) reported that foliar application of 2, 4-D (10 ppm) NAA (30 ppm) and Gibberellic acid (25 ppm) with dry grass mulching increased the number of fruit of Nagpur mandarin.

Barun and Kumar (2003) observed that foliar application of zinc sulphate $(0.5 \%)$, NAA (20 ppm) and urea @ 2\% increased yield in litchi cv. Purbi.

Yadav et al., (2004) reported that significant reduction in total fruit drop was observed when foliar feeding of NAA @ 10 ppm followed by NAA @ 20 ppm and NAA 10 $\mathrm{ppm}+\mathrm{ZnSO}_{4} @ 0.5 \%$ in ber (Zizyphus mauritiana Lamk.).

Birendra et al., (2006) observed that foliar application of NAA at 10,20,30 and $40 \mathrm{ppm}$, 2,4-5-T at 10, 20, 30 and $40 \mathrm{ppm}, 2,4,5-\mathrm{T}$ at 20, 40, 60 and $80 \mathrm{ppm}, \mathrm{GA} 3$ at 50, 100, 150 and $200 \mathrm{ppm}$ improved the flowering, fruit set and fruit retention of mango.

Sharma et al., (2008) reported that crop was sprayed with zinc sulphate $(0.5 \%)$, urea $(1.0 \%)$, potassium sulphate (1.0\%), NAA (20 $\mathrm{ppm}), \mathrm{GA} 3(50 \mathrm{ppm})$ and water as control at different growth stages. Foliar application of all the chemicals improved the yield and quality of ber fruits significantly over control. Srivastava et al., (2009) obtained foliar spray of GA3 (50 ppm) + 2, 4-D (10 ppm) + urea $(2 \%)$ increased the quality and fruit yield of aonla.

Katiyaret al., (2010) noted that pre-harvest spray of NAA, GA3 and urea increased the fruit size, weight and yield of ber cv. Banarasi Karaka.

Sharma et al., (2011) reported that foliar application of nutrients (urea $1.0 \%, \mathrm{ZnSO}_{4}$ $0.5 \%$, potassium sulphate $1.0 \%$ ) and growth regulators (GA3 $50 \mathrm{ppm}$ and NAA $20 \mathrm{ppm}$ ) significantly increased the fruit set, fruit retention and fruit yield of ber

Singh et al., (2011) reported that foliar application of GA3 $\neg$ at $50 \mathrm{ppm}$ increased berries weight, pulp content and yield of phalsa.

Nkansah et al., (2012) noted that GA3 (25 $\mathrm{ppm}$ ) and NAA (25 ppm) gave the best results in terms of increasing fruit set, fruit retention, number of fruits per cluster and per plant, fruit weight and yield of mango.

Kacha et al., (2012) observed that the application of NAA $150 \mathrm{ppm}$, significantly increased number of flowers per shoot (151.21), number of fruits per shoot (60.74), 100 fruits weight $(49.80 \mathrm{~g})$, juice percentage $(57.78 \%)$ and minimum seed percentage $(30.44 \%)$ and the maximum yield per plant $(1.71 \mathrm{~kg} / \mathrm{plant})$ and $\mathrm{kg}$ per hectare $(5800$ $\mathrm{kg} / \mathrm{ha}$ ) followed by NAA $200 \mathrm{ppm}$. The quality of fruits in terms of total soluble solids $(25.23 \%)$, reducing sugar $(2.01 \%)$ and total sugar $(5.74 \%)$ were significantly higher in treatment ethrel $1000 \mathrm{ppm}$ followed by ethrel $750 \mathrm{ppm}$. An application of GA3 $150 \mathrm{ppm}$ significantly reduced acidity $(2.55 \%)$ and 
increased ascorbic acid content (39.50\%) in phalsa fruits.

Kundu et al., (2013) obtained minimum fruit drop and maximum productivity was depicted in foliar and soil application of PP333 followed by foliar spray of GA3 on pear. However, fruit growth (length and width) and volume at maturity and total sugar content was recorded maximum in combined application of GA3 and BA.

Choudhary et al., (2013) The physical characters of fruit like maximum increase in diameter (horizontal and vertical), weight, volume and number of sacs per fruit, minimum days taken to first harvesting and complete harvesting was recorded with the spray of $100 \mathrm{ppm}$ GA3, which was closely followed by $30 \mathrm{ppm}$ 2,4-D. The minimum peel thickness, number of seeds per fruit and average seeds weight per fruit was recorded with 30 ppm 2, 4-D treatment. The maximum number of fruit per tree, fruit retention per cent and yield per plant and per hectare was recorded with the spray of $30 \mathrm{ppm} \mathrm{2,4-D}$ which was significantly higher to control.

Kachaet al., (2014) conducted an experiment on phalsa with ten treatments comprised of NAA (100, 150 and $200 \mathrm{ppm}), \mathrm{GA} 3$ (50, 100 and $150 \mathrm{ppm})$, Ethrel $(500,750$ and 1000 ppm) and control (water spray). The results showed that NAA $150 \mathrm{ppm}$ and ethrel 1000 ppm significantly increased the flower \& yield attributes and GA3 $150 \mathrm{ppm}$ improve quality characters of phalsa.

Rajput et al., (2015) concluded that the treatment T10 $(0.2 \%$ boron + GA3 $60 \mathrm{ppm}+$ NAA $150 \mathrm{ppm}+$ ethrel $750 \mathrm{ppm}$ ) was found best for physical parameters and treatment $\mathrm{T} 5$ $(0.2 \%$ boron + NAA $150 \mathrm{ppm})$ for yield was found best. As far as the relative economics of the treatment is concerned, the maximum net realization of Rs. $1,72,807$ per hectare with highest 1:6.6 cost benefit ratio (CBR) was obtained by the treatment T5 $(0.2 \%$ boron + NAA $150 \mathrm{ppm})$ as compared to other treatments. Therefore, the treatment T5 $(0.2 \%$ boron + NAA $150 \mathrm{ppm}$ ) is best among all treatment for higher production.

\section{Materials and Methods}

The experiment was conducted on twenty years old trees of phalsa at the Main Experimental Station, Department of Horticulture, NDUA\&T, Kumarganj, Faizabad (U.P.) during 2014-15.The experiment was laid out in randomized block design with 7 treatments and three replications. The treatment consisted two foliar applications of naphthalene acetic acid and gibberellic acid. The treatments were $\mathrm{T} 1$ Control (Water spray), T2 (NAA $100 \mathrm{ppm}$ ), T3 (NAA 150 ppm), T4 (NAA 200 ppm), T5 (GA3 50 ppm), T6 (GA3 100 ppm), T7 (GA3 $150 \mathrm{ppm})$. The treatments were imposed at two times first spray of plant growth regulators was done in Pre-blooming Stage and second spray just after fruit setting. The observations were recorded on the parameters viz. Length of shoot (m), Number of shoots per plant, Number of leaves per plant, Interndal length $(\mathrm{cm})$, Number of fruits per node, Number of fruiting nodes per shoot, Fruit yield per plant $(\mathrm{kg})$ and Fruit yield per ha (q). Statistical analyses of the data obtained in the different sets of experiments were calculated as suggested by Panse and Sukhatme (1985) and results were evaluated at $5 \%$ level of significance.

\section{Results and Discussion}

Plant growth regulators spray significantly affects the shoot length. However, the maximum $(2.52 \mathrm{~m})$ shoot length was measured with foliar spray of GA3 @ 150ppm followed by spray of NAA @ 100 ppm (Table 1). The increase in vegetative growth of the 
phalsa plant with the spray of plant growth regulators and may be attributed to the association of nitrogen in the synthesis of protoplasm and in the primary manufacture of amino acids and increased auxin activities. As a result, meristematic activities increased which in increase the vegetative growth. Similar results have also been reported by Karole and Tiwari (2016) with spray of NAA + GA3 + urea in ber and Kumar et al., (2014) in phalsa. Number of shoots per plant was also influenced significantly by the application of plant growth regulators. However, the maximum (123.33) number of shoots per plant was measured with foliar spray of GA3@150ppm followed with the spray of GA3 @100ppm (Table 1). Number of shoot per plant was increased with the application of plant growth regulators spray. Increase in plant growth parameters might be due to fact that gibberellin (given in the form of GA3 sprayed) is a constituent of protein which is essential for formation of protoplasm and thus, affecting cell division and cell elongation. All these contributed in enhancing shoot length and number of shoots per plant of phalsa. The present findings are in conformed to the report of Moon Young et al., (2003) in Satsuma mandarin and Kumar et al., (2014) in phalsa. The number of leaves per shoot increased significantly with the application of foliar feeding of plant growth regulators and the highest (61.46) number of leaves was obtained with spraying of GA3@150ppm (Table 1). The favorable effect of GA3 and NAA in promoting number of leaves might be due to abundant supply of GA3 on plant growth moreover, the increase in vegetative growth may be attributed to an increase uptake of these elements which being a constituent of protein component of protoplasm, favorably influenced chlorophyll content in leaves. All these factors contributed to cell multiplication, which has resulted in to better photosynthetic activity and it's translocation to promote better vegetative growth. Thus increased the number of leaves per shoot with the spray of GA3. The findings are in agreement with result of Karole and Tiwari (2016) with spray of NAA + GA3 + urea in ber and Singh et al., (2011) and Kumar et al., (2014) in phalsa. The internodal length was increased significantly with plant growth regulators.

Table.1 The effect of foliar feeding of $\mathrm{GA}_{3}$ and NAA onvegetative growth and yield of phalsa

\begin{tabular}{|c|c|c|c|c|c|c|c|c|}
\hline Treatments & $\begin{array}{l}\text { Shoot } \\
\text { length } \\
\text { (m) }\end{array}$ & $\begin{array}{l}\text { Shoots/ } \\
\text { plant }\end{array}$ & $\begin{array}{l}\text { leaves } \\
\text { per shoot }\end{array}$ & $\begin{array}{l}\text { Internod- } \\
\text { al length } \\
(\mathrm{cm})\end{array}$ & $\begin{array}{l}\text { fruits } \\
\text { /node }\end{array}$ & $\begin{array}{l}\text { fruiting } \\
\text { nodes/ } \\
\text { shoot }\end{array}$ & $\begin{array}{l}\text { Fruit } \\
\text { yield } \\
\text { (kg/plant) }\end{array}$ & $\begin{array}{l}\text { Fruit } \\
\text { yield } \\
\text { (q / ha) }\end{array}$ \\
\hline $\mathrm{T}_{1}$-Control (Water spray) & 1.78 & 78.33 & 43 & 5.06 & 9.46 & 9.93 & 3.95 & 43.87 \\
\hline $\mathrm{T}_{2}$-NAA @ 100 ppm & 2.04 & 84 & 47.66 & 5.4 & 9.8 & 10.8 & 4.37 & 48.54 \\
\hline T3-NAA@150 ppm & 2.28 & 84.66 & 51.13 & 5.3 & 10.16 & 10.26 & 4.64 & 51.62 \\
\hline $\mathrm{T}_{4}$-NAA@ $200 \mathrm{ppm}$ & 2.3 & 79.33 & 54.6 & 5.6 & 10.56 & 10.6 & 4.34 & 48.06 \\
\hline $\mathrm{T}_{5}-\mathrm{GA}_{3} @ 50 \mathrm{ppm}$ & 2.41 & 81.33 & 56.53 & 5.63 & 10.4 & 11.26 & 5.34 & 59.39 \\
\hline $\mathrm{T}_{6}-\mathrm{GA}_{3} @ 100 \mathrm{ppm}$ & 2.44 & 95 & 58.66 & 5.66 & 11.3 & 11.36 & 4.87 & 53.84 \\
\hline $\mathrm{T}_{7}-\mathrm{GA}_{3} @ 150 \mathrm{ppm}$ & 2.52 & 123.33 & 61.46 & 6.13 & 12.06 & 12.5 & 5.37 & 59.65 \\
\hline SEm \pm & 0.11 & 7.71 & 1.17 & 0.11 & 0.38 & 0.29 & 0.25 & 2.83 \\
\hline $\mathrm{CD}$ at $5 \%$ & 0.33 & 23.77 & 3.62 & 0.37 & 1.18 & 0.91 & 0.78 & 8.73 \\
\hline
\end{tabular}

The maximum $(6.13 \mathrm{~cm})$ inter nodal-length was achieved with foliar spray of GA3 @ 150 ppm (Table 1). Higher inter-nodal length achieved might be due to cell division and cell elongation growth enhancing properties of gibberellin reported by Singh et al., (2015) with the spray of 20 ppm GA3 and Kumar et al., (2014) in phalsa. The maximum (12.06) number of fruits per node was obtained with foliar spray of GA3 @150 ppm followed with 
the spray of NAA @ 200ppm (Table 1). The higher number of fruits per node might be due to fact that nitrogen is component of chlorophyll and gibberellic acid and auxin help in chlorophyll formation that regulate the buildup of proper $\mathrm{C}: \mathrm{N}$ ratio, which controls the flowering and fruiting of plants. It is also assumed that gibberellin and auxin play significant role in photosynthetic activity and better translocation of metabolites for developing fruit lets. These results are in close conformed to finding of Kumar et al., (2014) in phalsa. The maximum (12.50) number of fruiting nodes per shoot was counted with the spray of GA 3 @ 150 ppm (Table-1). It might be possible because Gibberellin causes vegetative growth for development of fruiting nodes. Gibberellin and auxin helps in the translocation of carbohydrates and other metabolites for better reproductive growth of plants. These results are in close conformed to finding of Kumar et al., (2014) in phalsa. A perusal of data regarding fruit yield clearly revealed that plant growth regulators spray significantly influenced fruit yield $(\mathrm{kg})$ per plant. The maximum $(5.37 \mathrm{~kg})$ fruit yield per plant was recorded with the spray of GA3 @ 150ppm followed by GA3 @ 50ppm (Table 1). This may be due to the better physiology of developing fruits in terms of better supply of water, and other compounds vital for their proper growth and development which resulted in improved size and yield as compared to NAA. These results are in close conformed with finding of Anawal et al., (2015) in pomegranate cv. Bhagwa, Rajput et al., (2015) in guava cv. L-49 and Sharma et al., (2008) in mango.

The increase in growth and yield attributes particularly number of per node and increased yield per plant which contributed towards such an increase in average yield per hectare. The maximum (59.65 q ha.) fruit yield per plant was recorded with the spray of GA3
@ 150ppm followed by GA3 @ 50ppm (Table $1)$. The present findings are in conformed with the result of Anawal et al., (2015) in pomegranate cv. Bhagwa and Rajput et al., (2015) in guava cv.L-49.

It may be concluded from the result obtained in present investigation that foliar application of $\mathrm{GA}_{3} 150 \mathrm{ppm}$ at pre-bloom stage and fruit setting was found most effective in increasing vegetative growth, yield. Hence $\mathrm{GA}_{3} 150 \mathrm{ppm}$ can be recommended for Phalsa growers for getting higher yield.

\section{References}

Barun and Kumar, Rajesh (2003). Effect of NAA, Zinc sulphate and urea on growth and yield of litchi (Sonn) cv. Purbi. Orissa J. Hort., 31 (1): 114-118.

Birendra, Prasad; Ray, R. N., Prasad, K. K., Choudhary, B.M. and Brahmachari, U.S. (2006). Effect of growth regulators on flowering, fruit set and fruit retention in Mango. J. Res. Birsa Agric. Uni., 18 (2): 257-260

Brahmachari, V. S. and Rani, R. (2001). Effect of growth substances on cracking and other physio-chemical composition of litchi. Orrisa J. Hort. 29 (1): 41-45.

Brahmachari V. S. and Rubi (2000). Effect of growth substances on fruit yield and physico-chemical composition of litchi fruit. Prog. Hort., 32 (1): 50-55.

Chandra, R., Manju; Rawat, S. S. and Singh, K. K. (2015). Effect of Foliar application of various growth regulators on yield and quality of aonla cv. NA- 7 . Int. J. Trop. Agri., 33 (3), JulySeptember.

Choudhary, H. D., Jain, M. C., Sharma, M. K. and Bhatnaga, P. (2013). Effect of plant growth regulators on growth and yield of nagpur mandarin (Citrus reticulata Blanco.). Asian J. Hort., 8 (2): 746-750. 
Chundawat and Randhava (1973). Reported that the foliar application of GA3, 2, 4$\mathrm{D}$ and 2, 4, 5-T, increased the fruit set over control in grape fruit cv. Duncan. The best result was obtained with application 750 ppm GA3 and $10 \mathrm{ppm}$ 2, 4, 5-T.

Debnath, A., Vanajalatha, K., Momin, U and Reddy, M. (2011). Effect of NAA, GA3, kinetin and ethrelonyieldand qualityin phalsa ( DC). Asian J. Hort., 6 (2):474-477.

Ghosh, S. N., Bera B., Roy, S. and Kundu A. (2009). Effect of plant growth regulators in yield and fruit quality in pomegranate C.V. Ruby. J. Hort. Sci., 4: 2 158-160

Bhosale, A.M. (2009). Effect of plant growth regulators and micro-nutrients on certain quality attributes of Kagzi lime (Citrus aurantifolla) Swingle. Int. J. Agri. Sci., 5: 1, 50-52.

Ghosh, S.N., Roy, S. and Bera, B. (2013). Effect of NAA on controlling fruit drop and yield of 'Banarasi Karaka' cultivar of bergrown in closespacing. Environ. Eco., 31(3): 1217-1219.

Grewal,G. P. S.,Singh,Z. and Singh,L. (2000). Effects of gibberellin A4/A7and blossom thinning on fruit set, retention, quality, shoot growth and return bloom of phalsa (Grewia asiatica L.). Acta Hort., 525: 463-466.

Ingle, H. V., Rathod, N. G. and Patil, D. R. (2001). Effect of growth regulators and mulching on quality of Nagpur Mandrin. Ann. Pl. Physiol., 15 (1): 8588 .

Kacha, H.L., Jat, G., and Patel, S. K. (2014). Performance of various plant growth regulators on yield and quality of phalsa (Grewia asiatica L.). Hort Flora Res. Spect., 3 (3): 292-294.

Kacha, H. L., Viradia, R. R., Leua, H. N., Jat, G. and Tank, A. K. (2012). Effect of NAA, GA3 and ethrel on yield and quality of phalsa (Grewia asiatica L.). Asian J. Hort., 7 (2): 242-245.

Kachave, D. B. and Bhosale, A. M. (2007). Effect of plant growth regulators and micro-nutrients on fruiting and yield parameters of Kagzi lime (Citrus aurantifolla) Swingle. Fruits Asian J. Hort., 2 (2): 75-79.

Karole, B. And Tiwari, R. (2016) Effect of pre-harvest spray of growth regulators and urea on growth, yield and quality of ber under malwa plateau conditions. Ann. Plant Soil Res., 18 (1): 18-22.

Kumar, S., Yadav, A. L., Vishwakarma, G. and Yadav, D. K. (2014) Effect of foliar feeding of nutrients and plant growth regulators on vegetative growth and yield of phalsa (Grewia Subinaequalis D.C.). Res. Environ. Life Sci., 7(4) 293294.

Kundu, M., Joshi, R., Rai, P.N. and Bist, L. D. (2013). Effect of bio-regulators on fruit growth, quality andproductivity of pear [Pyrus pyrifolia (Brum) Nakai] CV Gola under tarai condition. J. Appl. Horti., 15 (2): 106-109.

Oosthuyse, S. A. (1993). Effect of spray application of KNO3, Urea and Growth regulators on the yield of Tommy Atkins mango, Year book- SouthAfrican Mango Grower's Association, 13: 58-62.

Pandey, R. M. and Narwadrar, R. P. (1983). Studies on the induction of growth and flowering in mango (Mangifera indica L) cv. Dushehari. Indian Hort., 41 (3/4): $171-173$.

Prasad, A. and Baja, P. N. (1963). Effect of Alpha NAA on fruit set, size responding and yield of phalsa var. sharbati. Kanpur Agri. College J., 22 (1): 59-61.

Prasad, A. and Jauhari, O.S. (1963). Effect of 2, 4, 5-T and NAA on fruit drop and size of litchi fruits. Madras Agri. J., 50: 29-39. 
Rajput, R. P., Senjaliya, H. J., Vala, G. S. AND Mangroliya, G. S. (2015). Effect ofvarious plant growth regulators on yield and quality of guava (Psidium guajava L.) cv. L-49. Int. J. Agri. Sci., 11(1): 179-182.

Rema, J. and Sharma, V. P. (1991). Effect of plant growth regulators on yield and quality of phalsa (Grewia Subinaequalis L.). Food Sci. Tech. Abst. South Indian Hort., 39(6): 327-331.

Sharma, A. K., Singh, K. and Mishra, S. P. (2002). Effect of foliar spray of zinc sulphate, 2, 4, 5-T and GA3 on quality of Kagzi lime (Citrus aurantifoliaSwingle). Orissa J. of Hort., 30 (2): 115-118.

Sharma, A. K., Singh, K. and Mishra, S. P. (2003). Effect of foliar spray of zinc sulphate, 2, 4, 6-T and GA3 on quality of Kagzi lime (Citrus aurantifolia Swingle). Orissa J. Hort., 31 (2): 29-32.

Sharma, S. B. and Dhillon, B. S. (1984). Effect of zinc sulphate and growth regulators on the growth of litchi. Prog. Hort., 16 (1-2): 19-22.

Singh, Ashutosh Kumar; Kumar, Anil and Yadav, A. L. (2015). Effect of pruning intensity, foliar feeding of P.G.R. and micro nutrients on physico-chemical attributes of phalsa (Grewia subinaequalis) fruits. Res. Environ. Life Sci., 8 (4) 675-678.

Singh, G. C. and Singh, G. (1988). Effect of calcium nitrate and plant growth regulators on nutrient uptake by leaves and fruits on quality of guava. Prog. Hort., 20 (34): 241-245.

Singh, J. P., Kumar S., Katiyar P.N. and Dwivedi, A.K. (2011). Effect of calcium nitrate, GA3 and ethrel on fruiting, ripening and chemical traits of phalsa (Grewia subinaequalis D.C.) Ann. Hort., 4 (1): 72-76.

Sinha, A. H., Singh, C. and Jain B. P. (1999). Effect of plant growth substances and micro-nutrients on fruit set, fruit drop, fruit retention cracking of litchi C.V. Purbi. Ind. J. Hort., 56 (4): 309-311.

Srivastava, C. P., Singh, H. K., Vishwanath and Pratap, Bhanu (2009). Efficacy of foliar feeding of plant growth regulators along with urea on yield and quality of aonla (Emblica officinalis Gaertn). Cv. NA-7 fruits. Ann. Hort., 2 (1): 77-79.

Yadav I. S. and Panday, S. N. (1974). Effect of berry thinning and GA3 application on yield and quality of Pusa Seedless grapes (V. vinifera). Prog. Hort., 6(3): 81-87.

Yadav, B., Rana, G. A. and Bhatia, S. K. (2004). Response of NAA, urea and ZnSO4 on fruit drop in ber (Zizyphus mauritiana Lamk.). Haryana J. Hort. Sci., 33 (3/4): 181-182.

Young, M., Young, E. K., Ho Kim Chang Myung and Sangdok, K. (2003). Effects of foliar application of GA3 on flowering, vegetative shots, fruit set and fruit size and fruit quality of very earlymaturing Satsuma mandarin (Karan). Korean J. Hort. Sci. Tech., 21 (2): 110123.

\section{How to cite this article:}

Bhujbal Singh, A.L. Yadav and Ashok Kumar Meena. 2017. A Study on Foliar Feeding of GA3 and NAA on Vegetative Growth and Yield of Phalsa (Grewia Subinaequalis D.C.). Int.J.Curr.Microbiol.App.Sci. 6(6): 768-775. doi: https://doi.org/10.20546/ijcmas.2017.606.090 